\title{
Development and Evaluation of Tractor Drawn Ginger Harvester cum Elevator
}

\author{
Kawale Nagendra ${ }^{1 *}$, M. Anantachar ${ }^{1}$, Praveen Jholgikar ${ }^{2}$, M. Veerangouda ${ }^{1}$, \\ K.V. Prakash ${ }^{1}$, K.T. Ramappa ${ }^{3}$ and D. Krishnamurthy ${ }^{4}$ \\ ${ }^{1}$ Department of Farm Machinery \& Power Engineering, ${ }^{2}$ Department of Fruit Science, \\ ${ }^{3}$ Department of Processing \& Food Engineering, ${ }^{4}$ Department of Agronomy, UAS, \\ Raichur 584106 \&UHS, Bagalkot 587104, Karnataka, India
}

*Corresponding author

\section{A B S T R A C T}

The tractor drawn ginger harvester cum elevator was developed with an objective to have mechanical means for harvesting of ginger crop. The components were designed and developed keeping in view the relevant crop, soil and machine parameters. The machine

\section{Keywords}

Ginger harvester, harvester cum elevator, Draft, Field capacity, Field efficiency, Fuel consumption

\section{Article Info}

Accepted:

15 November 2018 Available Online: 10 December 2018 consisted of a main frame, digging blade, depth gauge wheel, vibration unit, power transmission system, and conveying mechanism. The performance evaluation of developed machine was evaluated at Chitta village of Bidar district of Karnataka State. The experiment was undertaken in red clay soil; the observed moisture content was 13.50 per cent moisture content $(\mathrm{db})$ at the time of harvesting. The size of the experiment plot was 0.2 ha was taken for observations. During field testing of machines, draft, digging efficiency, per cent damage of ginger rhizome and fuel consumption, separation index and conveying efficiency were calculated. The theoretical field capacity, actual field capacity and field efficiency were also measured. The ginger harvester cum elevator was tested at a forward speed of $2.5 \mathrm{~km} \mathrm{~h}^{-1}$. The draft and power requirement for harvesting ginger crop using harvester cum elevator was found to be $2625.82 \mathrm{~N}$ and $1.82 \mathrm{~kW}$ respectively. Fuel consumption for particular operation was observed to be $5.031 \mathrm{~h}^{-1}$. Theoretical field capacity, effective field capacity and field efficiency of ginger harvester cum elevator was calculated $0.22 \mathrm{ha} \mathrm{hr}^{-1}, 0.18 \mathrm{ha} \mathrm{hr}^{-1}$ and $81.80 \mathrm{ha} \mathrm{hr}^{-1}$ respectively. The digging efficiency, damage of rhizome, separation index and conveying efficiency of ginger harvester cum elevator was recorded to be $99.18 \mathrm{ha} \mathrm{hr}^{-1}, 1.06$ per cent, 85.38 per cent and 99.72 per cent respectively.

\section{Introduction}

Ginger (Zingiber officinale Roscoe,) is one of the most important cash crops and principal spice of India and abroad (Bartley and Jacobs, 2000). It is a perennial plant that grows to a height of 600 to $900 \mathrm{~mm}$ from underground rhizomes in tropical and subtropical climate (Mendi et al., 2009). Ginger is believed to be a native of South East Asia from where it was introduced to Africa and Caribbean regions and used in food and medicines for over 5000 
years (Purseglove et al., 1981). The total production of ginger in the world was 20,95,056 tones with the total acreage of 3,22,157 hectares. India, China, Nepal, Nigeria and Thailand are the major producers of ginger in the world (Anon, 2014). In India, it is grown in an area of $1,53,450$ hectares with the production of $7,99,860$ tones (Nair, 2017).

Ginger is one of the spices that support large number of farmers in the states of Kerala, Karnataka, Arunachal Pradesh, Orissa, West Bengal, Sikkim and Madhya Pradesh (Karthick et al., 2015). However, Karnataka, Orissa, Assam, Meghalaya, Arunachal Pradesh and Gujarat together contribute 65 per cent of the country's total production. In Karnataka, the ginger production was 0.019 million tonnes from an area of 0.0524 million ha, with an average productivity of 2.80 tonnes per ha (www.indiastat.com).

Harvesting is one of main important operation in ginger cultivation. In India, it is performed by manual method with the help of hand tools i.e., special fork type of spade/ pick axe, bullock drawn and power operated devices and by using traditional diggers drawn by tractors or power tillers. It was found that there is a noticeable damage to the crop during harvesting. However, most of the digging operation during ginger harvesting is done manually due to non availability of suitable devices. The post harvest studies of ginger indicated that, about 70 per cent of the rhizomes are spoiled and wasted due to the storage rots caused by rough harvesting and handling practices resulting in injury of skin and flesh of the rhizomes (Rattan et al., 1988). Sometimes, bullock operated wooden plough is also used for tuber crop harvesting. These conventional methods need more labour with less field capacity which increases cost of operation. On an average, about 600 man-h of labour per hectare is required for harvesting of root crops manually (Sharma and Varma 1986). This method of harvesting is highly labour intensive, tedious and time consuming. It is also a very difficult task on the part of farmer to get required labour force during the harvesting season for the timely harvesting of crop. To alleviate all this, there is a need to develop a suitable mechanical harvesting technology for ginger crops. The mechanization of ginger harvesting is need of the hour as it saves harvesting time, cost of harvesting, crop damage and reduce drudgery involved. Keeping in view of the above points in mind, the present study was undertaken with the objective of development and performance evaluation of tractor drawn ginger harvester cum elevator.

\section{Materials and Methods}

Designed and developed a ginger harvester cum elevator for harvesting ginger crop by considering soil, biometric and machine parameters utilizing PTO power of the tractor. The main purpose was to design the machine for harvesting ginger crop with minimum draft requirement, maximum digging efficiency, low damage to rhizome and less fuel consumption along with greater soil separation and conveying efficiency at economic cost of operation. The fabricated machine consisted of main frame, gear box housing, power transmission system, depth gauge wheel, digging unit, vibrating unit, ground wheel, elevator conveyor system and windrower.

The machine consisted of a main frame having dimensions 1640 x $1200 \mathrm{~mm}$ for mounting digging blade, vibration unit, power transmission system depth gauge wheel and elevator conveyor systems. Digger blade having length, width and thickness of $1000 \mathrm{x}$ $200 \times 10 \mathrm{~mm}$ respectively. The blade was mounted at an angle of 20 degree with the horizontal. 
Two depth gauge wheels having diameter of $450 \mathrm{~mm}$ were mounted at both sides of the blade with the spacing between two wheels being $1200 \mathrm{~mm}$. A vibration unit was provided immediately after the digging blade for loosening of soil from the dug crop by providing vibrations in the system. The length and diameter of the vibrator rod was 1180 and $40 \mathrm{~mm}$ respectively. The lifting rakes, curved in structure were provided above the vibrator rod at a distance of $100 \mathrm{~mm}$ and the length of the rakes were $83 \mathrm{~mm}$. Vibration unit receives the drive from PTO shaft of the machine through gear box.

The power transmission system has been made at two stages, first from PTO to machine gear box from which power is transmitted to the conveyor by a belt mechanism system and also the same power is transmitted to the vibration unit. A machine support over the ground wheel made of pneumatic wheel was provided at centre both sides of the harvester. The diameter and width of the wheel are 320 and $100 \mathrm{~mm}$ respectively. An elevator conveyor was attached behind the vibration unit. The soil-rhizome separating unit consisted of conveyor having dimensions of $1115 \times 1100 \mathrm{~mm}$. The conveyor unit consisted of MS rods spaced at $30 \mathrm{~mm}$. The angle of the elevator was kept at 20 degree to the vibration unit. Windrowers are provided in the conveying system for separation of soil particles from the rhizome and windrowing in one row at the rear of the machine. The power to the elevator conveyor was provided through a gear box by belt and pulley drive system. The detailed specifications of the harvester cum elevator as shown Table 1.

\section{Testing and evaluation of developed ginger harvester cum elevator}

Ginger (Mahima-2) crops were cultivated in the research field at Chitta village of Bidar district, Karnataka state, as per recommended agronomical practices. The total area of experiment was 4000 square meter. Matured crop was harvested using experimental set-up of mechanical ginger harvester cum elevator. The observations on performance parameters were recorded for each test run. All the test runs were replicated thrice to eliminate any experimental bias. As mentioned in Table 2 and 3. the experiments on test set-up were planned by varying blade type (Straight, Inverted $\mathrm{V}$ and Crescent,), rake angle $\left(15^{\circ}\right.$, $20^{\circ}$ and $\left.25^{\circ}\right)$ and speed of operation $(2.0,2.5$ and $3.0 \mathrm{~km} \cdot \mathrm{h}^{-1}$ ) and these independent variables were tested with dependent variables like: draft, digging percentage, per cent damage of rhizome and fuel consumption. Optimized the tool on the above parameters and further optimized tool were tested with independent variables of conveyer unit viz., angle of elevator and speed ratio of elevator and determined the performance parameter like soil separation index and conveying efficiency with their three replications. The moisture content of the soil was maintained constant at desired level by allowing the field to dry after irrigation and depth of operation was also optimized based on biometric properties. Soil bulk density was also measured randomly at five different places. All the experiments were conducted for each one bed lengths for every replication according to the plan of experiments.

The first test of experiment was carried out at straight blade with rake angle kept at 15 degree and the data was recorded at three different speeds of operation. The rake angle was next fixed at 20 degree and observations were recorded for three levels of speed of operation by keeping all other variables constant. Similarly, tests were conducted for rake angle of 25 degree and all performance observations were recorded. Each test run was replicated thrice. Similar set of experiments was carried out using inverted $\mathrm{V}$ blade and crescent blade. Thus a total number of 81 runs 
were completed and performance data was recorded. Ginger harvester working under test conditions is shown in Plate 1.

Data were recorded for weight of ginger plants harvested, weight of ginger plants not harvested, wt of rhizome damaged and weight of soil collected with ginger plant mass for a test length of $10 \mathrm{~m}$. From this test data, the following performance parameters were determined to evaluate the machine.

\section{Results and Discussion}

Performance evaluation of the developed tractor drawn ginger harvester cum elevator was carried out in an experimental field of Chitta village of Bidar district, Karnataka state during 2017-18. Results of the experiments on ginger digger and conveyor units were the basis for selection of design values of the prototype of tractor drawn ginger harvester cum elevator as detailed mentioned, a inverted $\mathrm{V}$ shape blade with rake angle of 20 degree and $2.5 \mathrm{~km} \mathrm{~h}^{-1}$ as selected (Fig. 1). Keeping in view of draft, digging efficiency, per cent damage of rhizome and fuel consumption of the harvester. The important design parameters of separating units were angle of elevator and speed ratio of elevator. The design values of angle of elevator and speed ratio of elevator was selected as 20 degree and 1.25, respectively. Keeping in view the best performance of machine in terms of soil separation index and conveying efficiency. The speed ratio of 1.0 to 1.5 the prototype was kept at 1.25. The overall performance of this mechanism was better in respect of draft, digging efficiency, per cent damage of rhizome, fuel consumption, soil separation index and conveying efficiency. The performance evaluations were calculated as per the standards (BIS Test code, IS 13818:1993) test procedure for root crop digger elevator.

The following design and operational parameters recommended for the final prototype of ginger harvester cum elevator are given in Table 4.

The ginger harvester cum elevator was evaluated under optimized parameters viz., inverted $\mathrm{V}$ blade, 20 degree rake angle and $2.5 \mathrm{~km} \mathrm{~h}^{-1}$ forward speed and angle of elevator 20 degree and speed ratio of elevator at 1.25:1. The prototype ginger harvester cum elevator was evaluated for 0.2 ha. The performance parameters and viz., depth of operation, width of operation, speed of operation, draft, digging efficiency, per cent damage of rhizome, fuel consumption, separation index, conveying efficiency, theoretical field capacity, effective field capacity and field efficiency were also recorded and presented in Table 5.

Plate.1 Testing of developed ginger harvester cum elevator

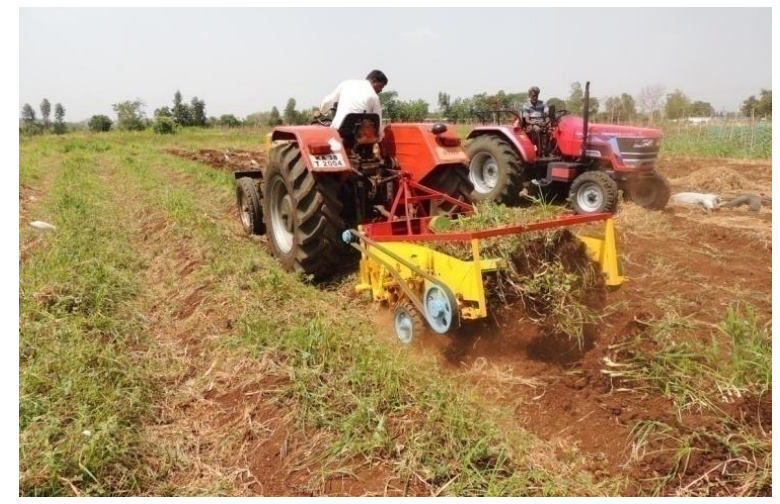


Table.1 Specification of major components of ginger harvester cum elevator

\begin{tabular}{|c|c|c|}
\hline SI. No. & Components & Specifications \\
\hline \multirow[t]{4}{*}{1} & \multicolumn{2}{|l|}{ Main frame } \\
\hline & Length, mm & 1640 \\
\hline & Width, mm & 1200 \\
\hline & Height, mm & 750 \\
\hline \multirow[t]{4}{*}{2} & \multicolumn{2}{|l|}{ Overall dimensions } \\
\hline & Length, mm & 1880 \\
\hline & Width, mm & 1550 \\
\hline & Height, mm & 1150 \\
\hline \multirow[t]{4}{*}{3} & \multicolumn{2}{|l|}{ Digger blade } \\
\hline & Length, mm & 1000 \\
\hline & Width, mm & 300 \\
\hline & Thickness & 10 \\
\hline \multirow[t]{3}{*}{4} & \multicolumn{2}{|l|}{ Depth Gauge wheel } \\
\hline & Number of wheel & 2 \\
\hline & Diameter of wheel, mm & 450 \\
\hline \multirow[t]{4}{*}{5} & \multicolumn{2}{|l|}{ Power Transmission system } \\
\hline & Gear reduction in gear box & $1: 4.5$ \\
\hline & Diameter of output shaft from the gear box, mm & 30 \\
\hline & Speed reduction by the sprocket & $2: 3$ \\
\hline \multirow[t]{3}{*}{6} & \multicolumn{2}{|l|}{ Ground wheel } \\
\hline & Diameter of wheel, mm & 320 \\
\hline & Width of wheel, mm & 100 \\
\hline \multirow[t]{3}{*}{7} & \multicolumn{2}{|l|}{ Conveyor unit } \\
\hline & Length, mm & 1100 \\
\hline & Width, mm & 1115 \\
\hline \multirow[t]{3}{*}{8} & Windrower & \\
\hline & Length, mm & 500 \\
\hline & Width, mm & 80 \\
\hline 9 & Weight of the harvester, $\mathrm{kg}$ & 490 \\
\hline
\end{tabular}


Table.2 Variables selected for the test for tool geometry of ginger harvester

\begin{tabular}{|r|l|c|l|}
\hline $\begin{array}{r}\text { SI. } \\
\text { No. }\end{array}$ & \multicolumn{1}{|c|}{ Variables } & Levels & \multicolumn{1}{c|}{$\begin{array}{c}\text { Parameters to be } \\
\text { measured }\end{array}$} \\
\hline & Independent variables & straight, inverted V, crescent, & \multicolumn{1}{c|}{$\begin{array}{c}\text { Dependent variables } \\
\text { 1.Draft }\end{array}$} \\
$\mathbf{1}$ & Type of blade & $15,20,25$ & 2.Digging efficiency \\
$\mathbf{2}$ & Rake angle, degrees & $2.0,2.5,3.0$ & 3. Per cent damage \\
$\mathbf{3}$ & Forward speed, km. $\mathrm{h}^{-1}$ & & 4. Fuel consumption \\
& & & \\
\hline & No. of treatments & $3 \times 3 \times 3=27$ & \\
& No. replications & 3 & \\
\hline
\end{tabular}

Table.3 Variables selected for the performance evaluation of elevator system for ginger harvester-cum- elevator

\begin{tabular}{|c|c|c|c|}
\hline SI. No. & Variables & Levels & Parameters to be measured \\
\hline $\begin{array}{l}1 \\
2\end{array}$ & $\begin{array}{l}\text { Independent variables of elevator } \\
\text { Angle of elevator, degrees } \\
\text { Speed ratio of elevator, } \mathrm{kmh}^{-1}\end{array}$ & $\begin{array}{l}3(15,20,25) \\
3(1: 1,1.25: 1,1.5: 1)\end{array}$ & $\begin{array}{l}\text { Dependent variables } \\
\text { 1. Conveying efficiency } \\
\text { 2. Soil separation efficiency }\end{array}$ \\
\hline & $\begin{array}{l}\text { No. of treatments } \\
\text { No. replications }\end{array}$ & $\begin{array}{l}3 \times 3=9 \\
3\end{array}$ & - \\
\hline
\end{tabular}

Table.4 Best optimal solutions of digging unit

\begin{tabular}{|l|l|l|}
\hline SI. No. & Variables & Optimal Values \\
\hline $\mathbf{1}$ & Tool geometry & Inverted V \\
\hline $\mathbf{2}$ & Rake angle & $20^{\circ}$ \\
\hline $\mathbf{3}$ & Forward speed & $2.5 \mathrm{~km} \mathrm{~h}^{-1}$ \\
\hline $\mathbf{4}$ & Angle of elevator & $20^{0}$ \\
\hline $\mathbf{5}$ & Speed ratio & $1.25: 1$ \\
\hline
\end{tabular}

Fig.1 Isometric view of ginger harvester cum elevator

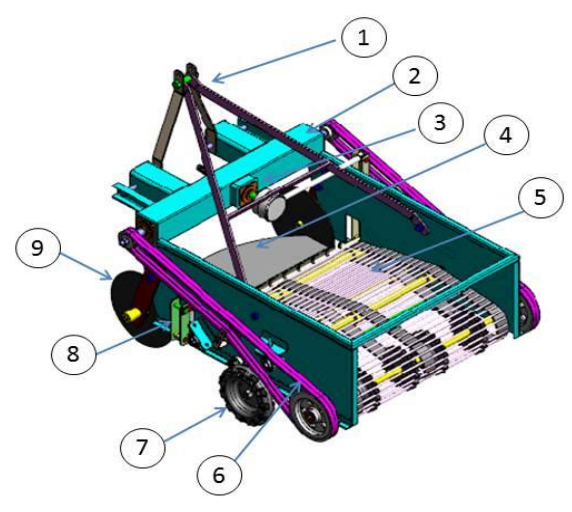

\begin{tabular}{|c|l|}
\hline S. No. & \multicolumn{1}{|c|}{ Particulars } \\
\hline 1 & Three point linkage \\
\hline 2 & Main frame \\
\hline 3 & Gear box \\
\hline 4 & Digging blade \\
\hline 5 & Conveyor \\
\hline 6 & Power transmission system \\
\hline 7 & Transport wheel \\
\hline 8 & Shaking mechanism \\
\hline 9 & Gauge wheel \\
\hline
\end{tabular}


Table.5 Performance results of optimized parameters of prototype of ginger harvester cum elevator

\begin{tabular}{|c|c|c|}
\hline Sl. No. & Particulars & Observations \\
\hline 1. & Actual operating time, min & 66.45 \\
\hline 2. & Time loss in turning, min & 18.45 \\
\hline 3. & Forward speed, $\mathrm{ms}^{-1}$ & 0.70 \\
\hline 4. & Area covered, $\mathrm{m}^{2}$ & 2000 \\
\hline 5. & Effective width of cut, mm & 900 \\
\hline 6. & Depth of cut, mm & 200 \\
\hline 7. & Effective field capacity, ha $\mathrm{h}^{-1}$ & 0.18 \\
\hline 8. & Theoretical field capacity, ha $\mathrm{h}^{-1}$ & 0.22 \\
\hline 9. & Field efficiency, $\%$ & 81.80 \\
\hline 10. & Draft, $\mathrm{N}$ & 2625.82 \\
\hline 11. & Digging efficiency, $\%$ & 99.18 \\
\hline 12. & Power requirement, $\mathrm{kW}$ & 1.83 \\
\hline 13. & Fuel consumption, $1 \mathrm{~h}^{-1}$ & 5.03 \\
\hline 14. & Soil separation index, $\%$ & 85.38 \\
\hline 15. & Conveying efficiency, $\%$ & 99.72 \\
\hline
\end{tabular}

The ginger harvester cum elevator was tested at a forward speed of $2.5 \mathrm{~km} \mathrm{~h}^{-1}$. The draft and power requirement for harvesting ginger crop using harvester cum elevator was measured and it was found to be $2625.82 \mathrm{~N}$ and $1.82 \mathrm{~kW}$ respectively. Fuel consumption for particular operation was observed to be $5.031 \mathrm{~h}^{-1}$. Theoretical field capacity, effective field capacity and field efficiency of ginger harvester cum elevator was calculated 0.22 ha $\mathrm{hr}^{-1}, \quad 0.18$ ha $\mathrm{hr}^{-1}$ and $81.80 \mathrm{ha} \mathrm{hr}^{-1}$ respectively. The digging efficiency, damage of rhizome, separation index and conveying efficiency of ginger harvester cum elevator was recorded to be $99.18 \mathrm{ha} \mathrm{hr}^{-1}, 1.06$ per cent, 85.38 per cent and 99.72 per cent respectively.

It is concluded that in the present study, a tractor drawn ginger harvester cum elevator was designed and developed. The major components of the harvester were main frame, digging blade, depth gauge wheel, vibration unit, power transmission system, and conveying mechanism. The developed prototype was tested at a forward speed of 2.5 $\mathrm{km} \mathrm{h}^{-1}$. The draft and power requirement for harvesting ginger crop using harvester cum elevator was measured and it was found to be $2625.82 \mathrm{~N}$ and $1.82 \mathrm{~kW}$ respectively. Fuel consumption for particular operation was observed to be $5.031 \mathrm{~h}^{-1}$. Theoretical field capacity, effective field capacity and field efficiency of ginger harvester cum elevator was calculated $0.22 \mathrm{ha} \mathrm{hr}^{-1}, 0.18 \mathrm{ha} \mathrm{hr}^{-1}$ and $81.80 \mathrm{ha} \mathrm{hr}^{-1}$ respectively. The digging efficiency, damage of rhizome, separation index and conveying efficiency of ginger harvester cum elevator was recorded to be $99.18 \mathrm{ha} \mathrm{hr}^{-1}, 1.06$ per cent, 85.38 per cent and 99.72 per cent respectively. The developed ginger harvester cum elevator was found very suitable for harvesting the ginger crop.

\section{References}

Anonymous., 2014, Food and agriculture organization, Rome.

Anonymous., 2016, www.indianstat.com

Bartley, J. and Jacobs, A., 2000, Effects of drying on flavour compounds in Australian-grown

IS 13818:1993, Indian standards on 
harvesting equipment-Tractor operated potato digger shakers- Test code, Bureau of Indian standards, Manak Bhavan,9 Bahadur Shah Zafar Marg, New Delhi.

Karthick, V., Alagumani, T. and Anbarassan, A., 2015, Growth and export performance of ginger in India- An economic analysis. J. Food Sci. Technol., 3(4): 21-29

Khura, T. K., Mishra, I. M. and Shrivastava, A. P., 2010, Some engineering properties of onion crop relevant to design of onion digger. J. Agril Engg., 47 (1): $1-8$.

Mendi, S. D., Nain, C. W., Mfopit, M. Y., Tanya, A., and Mbofung, M. F., 2009, Nutritional merits of a gingerspiced cheese fed to male wistar rats. Pakistan Journal of Nutrition. 8(3): 1415-1421.

Moayad, B., Zaied, A. M. EI, N., Mohammed, H. D. and Afraa, S. M., 2014, Development of powered groundnut harvester for small and medium holdings in North Kordofan State in
Western Sudan. World J. Agril Res., 2(3): 119-123.

Nair, G. K., 2017, Ginger exports lose flavor amid competition from Nigeria, China, The Hindu Business line: 1-2.

Purseglove, J. W., Brown, E. G., Green, C. L. and Robbins, S. R. J., 1981. Ginger, Indian Spices. 2: 447-531.

Rattan, R. S., Korla, B. N. and Dohroo, N. P., 1988, Performance of ginger varieties under Solan conditions of Himachal Pradesh. Proceedings of National Seminar on Chillies, Ginger and Turmeric., pp 71-73.

Sharma, A. P. and Verma, S. R., 1986, Design, development and field evaluation of an oscillatory potato digger. AMA., 17(3): 60-62.

Wajire, Pooja, N., Jadhav, M. V., Pareek, C. M., Thakare, S. H. and Khambalkar, V. P., 2018, Development and performance evaluation of tractor operated tuber rhizomes digger, Green Farming, 9(2): 383-386.

\section{How to cite this article:}

Kawale Nagendra, M. Anantachar, Praveen Jholgikar, M. Veerangouda, K.V. Prakash, K.T. Ramappa and Krishnamurthy, D. 2018. Development and Evaluation of Tractor Drawn Ginger Harvester cum Elevator. Int.J.Curr.Microbiol.App.Sci. 7(12): 1942-1949.

doi: https://doi.org/10.20546/ijcmas.2018.712.224 